\title{
Employability Skills for Sustainable Development and Supporting Industrial Revolution 4.0:
}

\author{
A Study for Polytechnic Curriculum Development
}

\author{
I Made Suarta*, I Ketut Suwintana \\ Department of Accounting \\ Politeknik Negeri Bali \\ Badung, Indonesia \\ *madesuarta@pnb.ac.id, tutswint@yahoo.com
}

\author{
I G P Fajar Pranadi Sudhana \\ Department of Tourism \\ Politeknik Negeri Bali \\ Badung, Indonesia \\ fpranadi@pnb.ac.id
}

\author{
Ni Kadek Dessy Hariyanti \\ Department of Bussiness Administration \\ Politeknik Negeri Bali \\ Badung, Indonesia \\ dessy_hariyanti@yahoo.com
}

\begin{abstract}
Polytechnic plays an important role in preparing the workforce to meet the needs of industrial revolution 4.0. The 4.0 industrial revolution is characterized by the increasing role of digital technology and automation in business processes. This condition affects the shifting of the workplace environment to be automatically, requires educated workers with meta-competence and multi-skills, capable of performing complex tasks and adapting to a rapidly changing work environment. The purpose of this paper is to find the employability skills attribute needed by the workforce in the industry revolution 4.0. The study was conducted by literature study, reviews surveys scholarly articles and any other sources relevant to employability skills issue, and by so doing, provides a description, summary, and critical evaluation of employability skills in relation to industrial revolution 4.0. Based on literature review, employers expected graduates to have a number of generic skills, such as: communication skill, creativity and innovation skill, problem solving and decision making, critical thinking, self-management, team work skill, and ability to learn. Employers also needed graduates to have a number of personal attributes such as: honesty, integrity, empathy, adaptability, independence, ethics and behavior. These attributes are very important to be embedded in the polytechnic education curriculum. Polytechnics curriculum needs to be developed to provide more space to develop student employability skills.
\end{abstract}

Keywords-the fourth industrial revolution, polytechnic education, curriculum development, employability skills

\section{INTRODUCTION}

Competence and competitiveness of Indonesian human resources still need to be improved. The Global Competitiveness Index Report 2017 - 2018 show that competence and competitiveness of Indonesian workers are still below Singapore, Malaysia and Thailand. Indonesia is ranked 36, while Singapore, Malaysia and Thailand are ranked 3rd, 23rd and 32nd respectively [1]. Meanwhile, based on the human development index published by UNDP in 2016, Indonesia is ranked 113th. Indonesia's ranking is still under Singapore, Brunei Darussalam, Malaysia, and Thailand [2]. These facts provide an overview of Indonesia's competitiveness internationally, as well as relative to countries in Southeast Asia, and the quality of graduates of higher education still needs to be addressed.

The industrial revolution 4.0 eras require well-educated workers with meta-competence and multi-skills capable of performing complex tasks and adapting to rapidly changing work environments. In order to produce graduates who can compete in the global age, it is necessary to revitalize the curriculum of vocational education and training according to the needs of the labor market [3]. Revitalization is done to respond the needs world of work on the competence of higher education graduates. The curriculum is a systematic choice of knowledge, skills, and attitudes viewed as the goal of educational reform in order to produce qualified graduates [4]. The role of higher vocational education such as Polytechnic will be very important because it can produce skilled workers according to industry needs.

The orientation of vocational education curriculum needs to be changed from competency-based outcomes to capabilitybased. Revitalization of higher vocational education curriculum is intended to produce capable graduates to perform tasks in their field of work [5]. The capability means that in addition to having knowledge and technical skills in a particular field, it also has a number of employability skills that can be transferred into various fields of work such as communication skills, complex problem-solving skills, team-work skills, and adaptability.

The shifting orientation of higher education from competency-based outcomes to capabilities requires updating 
the curriculum platform. This paper intends to elaborate and review the literature on important aspects in the development and strengthening of the higher vocational education curriculum. The objectives of this paper are: (1) To examine the development of industrial revolution 4.0 and its implications for the labor market; (2) Identify the importance of employability skills required by graduates of vocational education in entering the world of work; and (3) Assessing the vocational higher education curriculum platform that is able to adapt to the needs today's world of work. The scope of the discussion is limited to the critical aspects of current industrial development and its implications for the world of work, as well as to examine the various employability skills required by graduate higher vocational education to enter the workforce.

\section{METHODOLOGY}

This study reviews surveys scholarly articles and any other sources relevant to employability skills issue, and by so doing, provides a description, summary, and critical evaluation of employability skills in the context of EAC era. The study was conducted with argumentative and integrative literature review design [6-9]. Argumentative literature review examines literature selectively in order to support or refute an argument, deeply imbedded assumption, or philosophical problem already established in the literature. The purpose is to develop a body of literature that establishes a contrarian viewpoint. Given the value-laden nature of some social science research, argumentative approaches to analyzing the literature can be a legitimate and important form of discourse. Integrative literature review considered a form of research that reviews, critiques, and synthesizes representative literature on a topic in an integrated way such that new frameworks and perspectives on the topic are generated. The body of literature includes all studies that address related or identical hypotheses or research problems. A well-done integrative review meets the same standards as primary research in regard to clarity, rigor, and replication.

The literature review conducted in four stages, namely: (1) Problem formulation, is the stage of formulating the topic or field being examined and the problem. In this study, topics or fields examined are employers' demand of employability skills in the AEC era. (2) Literature search is the stage of finding materials relevant to the subject being explored. The literature search is done using the search engine https://www.google.com/, with pdf document type. (3) Data evaluation is the stage of determining which literature makes a significant contribution to the understanding of the topic. Document priority is scholarly articles journal and any other sources relevant to employability skills issue. (4) Analysis and interpretation, is the stage for discussing the findings and conclusions of pertinent literature. In this stage also developed a theoretical or conceptual framework of employability skills required ASEAN job market.

\section{RESULTS AND DISCUSSION}

\section{A. Industrial Revolution and Its Implications for the World of Work}

The Fourth Industrial Revolution is a term to indicate the development of industrial systems that integrate advanced information technologies in the production process, first appeared in Germany in 2011. The impact of these industrial developments is increased production efficiency due to use of digital technology and automation, as well as changes in the composition of employment [10]. Characteristics of the industrial revolution include digitalization, optimization and customization of production, automation and adaption, human machine interaction, value added services and businesses, automatic data exchange and communication, and use of internet technology [11]

The changing in the fourth industrial revolution era had an effect on the workplace character, so that the skills needed also changing. An article entitled "The Top 5 Jobs Robots Will Take First", identifies a list of the top five jobs that will be performed automatically: (1) Middle management; (2) Commodity salespeople; (3) Report writers, journalists, authors, and announcers; (4) Accountants and bookkeepers; and (5) Doctors [12]. The fourth industrial revolution requires well-educated workers with meta-competence and multi-skills capable of performing complex tasks and adapting to rapidly changing work environments.

Vocational Education needs to anticipate the development of this industrial revolution, by revitalizing the curriculum. The curriculum and learning methods need to adapt to an increasingly competitive business and industry and keep pace with the development of digital technology and automation. The workplace character in the fourth industrial revolution era is characterized by five skills: Associating, Questioning, Observing, Networking, and Experimenting [13]. These five skills are seen as the most important types of meta-competence skills adopted in the development of a higher vocational education curriculum.

\section{B. The Importance of Employability Skills}

The term 'employability' has been used for many years in the context of debates about employment and labor markets, and necessary for effective participation in the workforce. Employability skills was used interchangeably with other terms such as generic skills, soft skills, transferable skills, nontechnical skills, core skills, key skills, essential skills, and $21^{\text {st }}$ century skills [14]. In recent years, employability skills have become an important issue in the national, regional, and international employment markets. Employability relates to the ability to be in employment, the set of characteristics that increase the chances of an individual being in work [15]. Sometimes definitions go a step further than simply focusing on the ability to secure employment, and specifically include the ability to sustain employment and to progress within work too.

Many experts and researchers define employability skills, some of which are Lankard [16], Overtoom [17], and Yorke [18]. The definition of employability skills provided has a 
common meaning, emphasizing the non-technical skills that must be possessed by graduates as well as workers. The changing nature of today's employment expects the workers to operate independently in roles that require problem-solving and decision-making skills, improving collaboration and team works; employers need creative, flexible workers who have a broad range of communication and interpersonal skills. These skills are skills that can be transferred to other areas of work, necessary for career success at all levels of employment and for all levels of education.

Many countries have developed conceptual framework employability skills and have been used as a reference by researchers. USA, Canada, Australia, and the United Kingdom are countries that intensely review and develop employability skills frameworks. Since 1990, two agencies in the United States namely the American Society for Training and Development (ASTD), and the Secretary's Commission on Achieving Necessary Skills (SCANS) have been pioneers in the development of employability skills frameworks [17]. The SCANS study found 36 skills, including the ability to use 5 competencies efficiently (resources, interpersonal skills, information, systems, and technology) based on a 3-part foundation of basic skills, thinking skills, and personal qualities.

The study of employability skills in Canada was conducted by the Conference Board of Canada (CBC) in 1996. According to the CBC document, employability skills can also be applied and used beyond the workplace in a range of daily activities. The employability skills framework developed consists of three main skill groups, namely: fundamental skills, personal management skills, and teamwork skills. Each group is composed of a number of skills. For example, fundamental skills consist of communication skills, managing information, use numbers, think and solve problems [19].

Employability skills study in Australia began in the 1980s by focusing on generic skills. In 1992, the Mayer Committee published a report on the generic skills required by industry in Australia [14]. Furthermore, the Business Council of Australia and the Australian Chamber of Commerce and Industry (BCA/ACCI) in 2002 conducted a comprehensive study of the skills that many workers need in order to succeed in the career. The results of this study are outlined in Employability skills for the future, provides the starting point for any discussion of employability skills in higher education in Australia. The report identifies a number of personal attributes required for today's employees and eight skill groups to describe and define employability skills. The eight skill groupings are: communication skills, team work skills, problem-solving skills, initiative and enterprise skills, planning and organizing skills, self-management skills, learning skills, and technology skills [20].

The Higher Education Academy conducts a study of employability skills in the United Kingdom, and offers a wide range of perspectives on the graduate's employability. In the Learning and Employability Series documents, employability defined as "a set of skills, knowledge and personal attributes that make an individual more likely to gain employment and be successful in their chosen occupations, which benefits themselves, the workforce, the community and the economy" [21]. The employability skills framework consists of personal qualities, core skills, and process skills. Each skill groups made up of a number of aspects.

In the ASEAN perspective, UNESCO Bangkok conducted a study on the graduate employability of university in selected ASEAN countries. The main findings of the employability frameworks refer to a wide range of attributes and competencies that enable the job seekers to gain and maintain employment such as, but not limited to, the following: communication skills; logical, analytical and problem solving skills; personality, confidence, and integrity; flexibility and adaptability; innovation and creativity; and team spirit [22]. Education systems in the Asia-Pacific region have integrated "the transversal competencies", as generic skills are critical for people to meet the new needs of society and compete in the global workforce. UNESCO Bangkok's new publication, examines how different countries and economies in the AsiaPacific region define and apply such transversal competencies in their education policies and practices [23]. The research conducted by Education Research Institutes Network (ERINet) concluded UNESCO Framework for Transversal Competencies consisting of five broad domains of skills, competencies, values and/or attributes. These are: critical and innovative thinking; inter-personal skills; intra-personal skills; global citizenship; and media and information literacy. Each domain of transversal competencies consists of a number of skill attributes.

\section{Higher Vocational Education Curriculum Platform}

The National Standard of Higher Education (SN-DIKTI), states that the curriculum is a set of plans and arrangements concerning graduate learning outcomes, study materials, processes and assessment used as guidelines for the implementation of study programs [24]. The graduate learning outcomes include: 1) Attitudes and Values; 2) Knowledge; 3) General Skills; and 4) Specific Skills. As discussed in the previous section, today's world of work requires well-educated workers with meta-competence and multi-skills to be able perform complex tasks and adapt to a rapidly changing work environment. The curriculum and learning on vocational education needs to be revitalized from competency-based to capability-based outcomes.

The development of graduates' employability skills will be a cornerstone in the face of an ever-changing work situation. The research conducted McMurray et al. shows the general skills demanded of graduates when entering the workforce such as: communication skills, team working skills, decision-making skills, organizational skills, interpersonal skills, willingness to learn, motivation, integrity, self-awareness, adaptability, intellectual ability, and confidence [25]. Research conducted by Maxwell et al. also find communication skills and problem solving occupy the highest rankings according to the employer and urgent to be included in curriculum design [26].

Graduates' capabilities are reflected in attitudes and values, as well as general skills that support the successful execution of tasks in the workplace. Research conducted by the author in 2017 on job advertisements published in national newspaper 
concluded that employability skills consist of generic skills and personal attributes [27]. Generic skills consist of a number of transferable skills: (1) communication skills, (2) teamwork skills, (3) problem solving skills, (4) creativity and innovation skills, (5) leadership skills, (6) self-managing skills, and (7) self-learning skills. Personal attributes are personal characteristics related to attitudes and values, consisting of: (1) honesty, (2) accuracy, (3) independence, (4) appearance, (5) openness, (6) ethics and behavior, and (7) a number of other characters. The results of this study can be adapted in order to develop a platform of higher vocational education curriculum oriented capability-based.

The proposed curriculum platform is general, uncharted by education level. Therefore, this proposed still need to be studied further in order to produce the basic curriculum framework for each level of higher education vocational. This is important so that the resulting curriculum content is not too focused on aspects of knowledge and technical skills. There is a need to balance with the employability skills component, because this work skill is needed in the workplace.

\section{CONCLUSION}

After the text edit has been completed, the paper is ready for the template. Duplicate the template file by using the Save As command, and use the naming convention prescribed by your conference for the name of your paper. In this newly created file, highlight all of the contents and import your prepared text file. You are now ready to style your paper; use the scroll down window on the left of the MS Word Formatting toolbar.

\section{REFERENCES}

[1] The World Economic Forum (WEF), The Global Competitiveness Index Index 2017 - 2018. Geneva: The World Economic Forum, 2017.

[2] The United Nations Development Programme (UNDP), Human Development Report 2016: Human Development for Everyone. New York: The United Nations Development Programme, 2016.

[3] G.S. Mouzakitis, "The role of vocational education and training curricula in economic development," Procedia Social and Behavioral Sciences, vol. 2, no.2010, pp. 3914-3920, 2010.

[4] P. Stabback, "What Makes a Quality Curriculum? Current and Critical Issues in Curriculum and Learningm," UNESCO: International Bureau of Education, 2016.

[5] W. Kamdi, Higher Education 4.0. Kompas Daily, Saturday 3 March 2018, page 6 .

[6] A. Fink, Conducting Research Literature Reviews: From the Internet to Paper. 2nd ed. Thousand Oaks, CA: Sage Publications, 2005

[7] C. Hart, Doing a Literature Review: Releasing the Social Science Research Imagination. Thousand Oaks, CA: Sage Publications, 1998.
[8] J. Jesson, Doing Your Literature Review: Traditional and Systematic Techniques. Los Angeles, CA: Sage Publications, 2011.

[9] D. Ridley, The Literature Review: A Step-by-Step Guide for Students. 2nd ed. Los Angeles, CA: Sage Publications, 2012.

[10] R. Samans and N. Davis, Advancing Human - Centred Economic Progress in the Fourth Industrial Revolution A Leadership Agenda for G20 Governments, 2017.

[11] The World Economic Forum (WEF), The Future of Jobs Employment, Skills and Workforce Strategy for the Fourth Industrial Revolution, 2016.

[12] S. Palmer, The 5 Jobs Robots Will Take First, 2017.

[13] J. Dyer, H. Gregersen and C.M. Christensen, The Innovator's DNA: Mastering the Five Skills of Disruptive Innovators. Boston, Massachusetts: Harvard Business Review Press, 2011.

[14] NCVER, Defining generic skills: At a glance. Adelaide, Australia: National Centre for Vocational Education Research (NCVER), 2003.

[15] V. Belt, P. Drake and K. Chapman, "Employability Skills: A Research and Policy Briefing. Briefing Paper Series, UK Commission for Employment and Skills," 2010

[16] B.A. Lankard, Employability--The fifth basic skill. ERIC Digest No. 104, 1990.

[17] C. Overtoom, Employability skills: An update. ERIC Digest No. 220 Columbus, Ohio: ERIC Clearinghouse on Adult, Career, and Vocational Education, 2000.

[18] M. Yorke, Employability in higher education: What it is - What it is not York, United Kingdom: The Higher Education Academy, 2006.

[19] The Conference Board of Canada (CBC), Employability skills 2000+, 2000.

[20] BCA/ACCI, Employability skills for the future. A Report by the Australian Chamber of Commerce and Industry (ACCI) and the Business Council of Australia (BCA) for the Department of Education, Science and Training, Canberra, 2002.

[21] M. Yorke and P.T. Knight, Embedding employability into the curriculum. York, United Kingdom: The Higher Education Academy, 2006

[22] UNESCO Bangkok Office, Graduate Employability in Asia, 2012.

[23] UNESCO Bangkok Office, 2013 Asia-Pacific Education Research Institutes Network (Eri-Net) Regional Study On Transversal Competencies in Education Policy \& Practice, 2015.

[24] Ministry of Research, Technology and Higher Education (Kemenristekdikti), Minister of Research, Technology and Higher Education Regulation No. 44 of 2015 on National Standards of Higher Education. Jakarta: Ministry of Research, Technology and Higher Education, 2015.

[25] S. McMurray, M. Dutton, R.W. McQuaid and A. Richard, Employe Demands from Business Graduates. Education + Training, vol. 58, no. 1 pp. 112-132, 2016.

[26] G. Maxwell, B. Scott, D. Macfarlane, and E. Williamson, "Employers as stakeholders in postgraduate employability skills development," International Journal of Management Education, vol. 8, no. 2, pp. 1-11, 2010 .

[27] I.M. Suarta, I.K. Suwintana, I.G.P. Fajar Pranadi Sudhana, N.K. Dessy Harriyanti, Development of Measurement Model and Employability Skills Assessment Tool for Vocational Higher Education Students. YearEnd Report of Social Research, Humanities, and Education (Unpublished). Badung: Politeknik Negeri Bali, 2017. 